\title{
Sustainable use of plants in coastal areas of Istanbul
}

\author{
Doğanay Yener ${ }^{a, *}$ (iD
}

\begin{abstract}
The coasts, which are considered as part of the land that limits the sea, are important living spaces for many living things. People have used the coast throughout history for a wide variety of activities. Rapid urbanization increased the intensity of this usage and in time the coastal areas began to be insufficient for the use of the people and then the concept of coastal landfill was emerged. In this study, woody plants in the coastal areas which have a great contribution to the landscaping of the city of Istanbul were evaluated. For this purpose, the most important coastal areas of the city, Sarlyer in the north, Avcilar, Maltepe and Kartal in the south were determined as examples and the woody plants used primarily in these areas were determined. Then these plants were evaluated by taking into consideration the ecological tolerance criteria (frost, drought, salinity and air pollution). As a result of the field studies carried out in the Sariyer, Avcilar, Kartal and Maltepe coastal areas, totally 51 woody plant taxa belonging to 26 families were identified. 37 of the identified woody plants were angiosperm and 14 were gymnosperm taxa. It is also identified that $28.57 \%$ of gymnospermae and $21.62 \%$ angiospermae taxa have a high salinity tolerance and their use in coastal areas is appropriate; $35.71 \%$ of gymnospermae and $35.14 \%$ of angiospermae taxa doesn't have a salinity tolerance so they shouldn't be used in coastal areas.
\end{abstract}

Keywords: Woody plants, Ecological tolerance, Landscaping, Salinity, Istanbul

\section{İstanbul kıyı alanları bitkilerinin sürdürülebilir kullanımı}

\begin{abstract}
Özet: Denizi sınırlayan toprak parçası olarak kabul edilen kıyılar, birçok canlı için önemli yaşam alanlarıdır. İnsanlar tarih boyunca kıyıları çok çeşitli faaliyetler için kullanmıştır. Hızlı kentleşme bu kullanım yoğunluğunu artırmış, zamanla kıyı alanları kentin kullanımına yetmemeye başlamış ve beraberinde kıyı dolgu alanı kavramı ortaya çıkmıștır. Bu çalışmada İstanbul kentinin peyzajına büyük katkısı bulunan kıyı dolgu alanlarındaki odunsu bitkiler değerlendirilmiştir. Bu amaçla kentin en önemli kıyı dolgu alanlarından kuzeyde Sarıyer, güneyde Avcılar, Maltepe ve Kartal kıyı dolgu alanları örnek alan olarak belirlenmis ve öncelikle buralarda kullanılan odunsu bitkiler tespit edilmiştir. Daha sonra da bu bitkilerin ekolojik tolerans (don, kuraklık, tuzluluk ve hava kirliliği) kriterleri dikkate alınarak değerlendirilmiştir. Sarıyer, Avcılar, Kartal ve Maltepe kıyı dolgu alanlarında gerçekleştirilen arazi çalışmaları sonucunda toplamda 26 familyaya ait 51 odunsu bitki taksonu tespit edilmiştir. Tespit edilen odunsu bitkilerin 37'si angiosperm, 14'ü ise gymnosperm taksonudur. Ayrica \%28.57 gymnosperm ve \%21.62 angiosperm taksonlarının tuzluluk toleransının yüksek olduğu ve kıyı bölgelerinde kullanımlarının uygun olduğu tespit edilirken; gymnosperm taksonlarının \%35.71'i ve angiosperm taksonlarının \%35.14' ünün tuzluluk toleransına sahip olmadığı ve bu yüzden kıyı bölgelerinde kesinlikle kullanılmaması gerektiği sonucuna varılmıştır.

Anahtar kelimeler: Odunsu bitkiler, Ekolojik tolerans, Peyzaj düzenleme, Tuzluluk, İstanbul
\end{abstract}

\section{Introduction}

Since the 1930s, coastal areas have been widely used to prevent coastal erosion and also to increase coastal use. Istanbul which is the most important city of Turkey, is very rich in terms of coastal areas because of its situation between the Black Sea and the Marmara Sea. When we look at the history of Istanbul, it is seen that the first settlements were established near the water and commercial relations were provided by sea. The coastal areas, which cannot meet the needs, have been expanded by being filled in time, in line with the population growth and rapid urbanization in the city. Today, $90 \%$ of the coastal areas of the city have lost their naturalness and turned into a coastal landfill. As a result, we can say that the city of Istanbul faced intense coastal consumption.

Ecological approaches have begun to gain importance in the landscape design of the city in order to ensure the sustainability of urban green areas and to provide environmentally sensitive urban development (Korkut et al., 2017). The coastal areas, which are the subject of the study, are one of the most difficult places in terms of soft landscape arrangements. It has salty water effect coming from the sea, strong winds, moisture and also it has limited development area because of the filler soil (Korkut, 1992). In this context, it is again seen that suitable plant use and creating sustainable landscapes in the coastal areas where the planting studies are realy difficult, is an important issue.

As a result of observations made in the coastal areas of Istanbul, it was determined that some species was in conformity with the coastal microclimate, while other species could not survive in the coastal areas. Using the suitable plant species on the coastal areas has become an important subject. As a result of the studies carried out, it was understood that the species suitable for use in the coastal areas should be classified as suitable species to the

\footnotetext{
$\triangle$ a Istanbul University-Cerrahpasa, Faculty of Forestry, Department of Landscape Architecture, 34473, Bahcekoy, Istanbul- Turkey

@ * Corresponding author (İletişim yazarı): doganay@ istanbul.edu.tr

$\checkmark \quad$ Received (Geliş tarihi): 11.11.2019, Accepted (Kabul tarihi): 01.04.2020
}

Citation (Atıf): Yener, D., 2020. Sustainable use of plants in coastal areas of Istanbul. Turkish Journal of Forestry, 21(2): 123-130. DOI: $10.18182 / \mathrm{tjf} .645461$ 
front shore area and back shore area (Türer, 1999). The use of plant species which is tolerant to salty water and coastal soil conditions should be used in the nearest parts of the sea, and secondly tolerant species should be used in the back part of the coast (Ürgenç, 1998).

In this study, the evaluation of woody plant taxa used in the coastal landscape areas of Istanbul, which is the most important metropolis of Turkey, has been made according to the ecological tolerance criteria. In this way, it is aimed to ensure sustainability in the coastal areas by using ecologically tolerant plants suitable for the ecological characteristics of the area.

\section{Materials and methods}

\subsection{Research material and study area}

Istanbul is located at the point where the continents of Europe and Asia are connected. Geographically, it is between $41^{\circ} 33^{\prime}-40^{\circ} 28^{\prime}$ north latitudes and $28^{\circ} 01^{\prime}-29^{\circ}$ $55^{\prime}$ east longitudes. Istanbul Province; has a land of 5712 $\mathrm{km}^{2}$ surface area (İBB, 2006).

The research area is located in the central part of the Marmara Region. The provincial area is administratively adjacent to the provinces of Tekirdağ and Kurklareli from the west and northwest. In the middle part, the Black Sea is combined with the Sea of Marmara. The Bosphorus, separates the continents of Asia and Europe and divides Istanbul into two parts. The Black Sea on the north and the Marmara Sea on the south clearly surround the area (Gönensin, 2002).

According to the studies carried out by Özyuvac1 (1999); Istanbul is located in the submediterran climate zone. Istanbul climate; shows a special situation within the influence of the Black Sea, Balkans and the Anatolian continental climate. Winters are quite cold. Snowfall is normal and more frequent frost occurs. In summer, drought and evaporation are less severe, relative humidity and cloudiness are more severe.

The average annual temperature in İstanbul is $14.5^{\circ} \mathrm{C}$. The average low temperature is seen on February with 6.0 ${ }^{\circ} \mathrm{C}$ and the average high temperature is seen on July with $23.9{ }^{\circ} \mathrm{C}$. The average annual high temperature of $18.5{ }^{\circ} \mathrm{C}$ and an average low temperature of $11^{\circ} \mathrm{C}$ indicates that there are no extreme degrees that will force the natural life (Yener, 2012).

This study was carried out in some of the coastal landscape areas of Istanbul. The research material consists of coastal areas located in Sariyer, Maltepe, Avcilar and Kartal regions of Istanbul which are shown in the map of Istanbul on Figure 1.

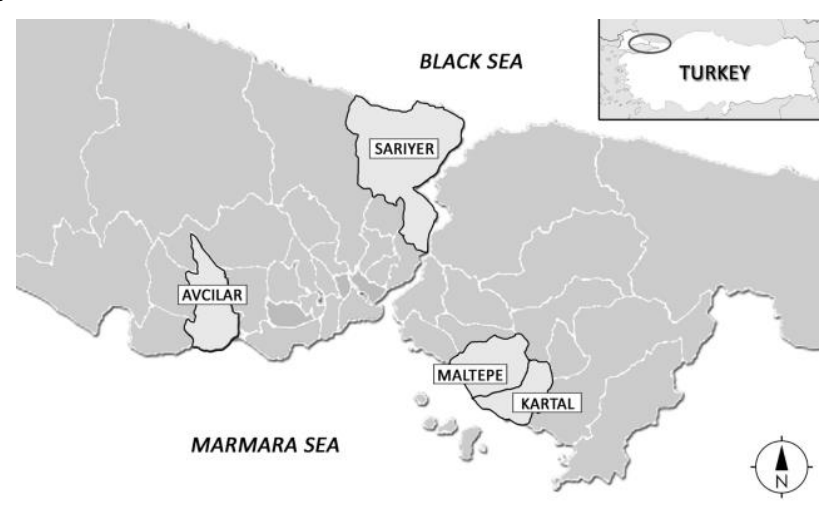

Figure 1. Research area

\subsection{Method}

This study, in which ecological tolerances of the plants used in some coastal areas of Istanbul were evaluated, was carried out in three stages. In the first stage, plant taxa in coastal areas were determined. For this purpose, identification of plant species were made which were collected from the coastal areas (Brickell, 1994; Davis, 1965-1988; Dirr, 1992; Hillier, 2001; Krussmann, 1985; 1986; Orçun, 1972; Pamay, 1992; 1993; Polunin, 1969; The Gymnospermae Database, 2019; Yaltırık, 1988; 1993; Yaltırik and Efe, 2000).

In the second stage of the study, the distribution of plant taxa according to the sample areas, their light tolerances and the other ecological tolerances (frost, drought, salt and air pollution) were determined by different literature reviews. The determined species are categorized by sun, sun/partial shade and shade, in terms of light tolerances. Ecological tolerances ranged from 1 to 3 (1: Not Tolerant, 2: Moderately Tolerant, 3: Tolerant) and a scale was created and the species determined were evaluated according to this scale (Barış, 2014; Bhardwaj and Singh, 2015; Escobedo and Chacalo, 2008; Gilman and Watson, 1993; Grahn and Stigsdotter, 2003; Güvenç and Demiroğlu, 2016; Hopkins and Al-Yahyai, 2015; PFAF, 2009; Plants, 2017; Rayno, 2014; Wade and Midcap, 2007).

In the third stage of the study, SPSS 22 package program was used in the evaluation of the data and also frequency distribution and One-Way Anova test were used. Different groups were identified by Duncan test and marked with the level $\mathrm{p} \leq 0.05$.

\section{Results}

\subsection{Evaluation of woody plants in terms of species}

When the distribution of the plants used in the coastal landscape areas of Istanbul by families, genus, species and subspecies examined, it has been identified that totaly there has been 51 taxa, 38 genus belonging to 26 families. The identified taxa were given according to their families in Table 1. It is seen that $72.55 \%$ of them is belonging to Angiospermae and $27.45 \%$ of these plants are Gymnospermae taxa. 
Table 1. Plant species, subspecies, varieties and cultivars of woody plants used in coastal landscape areas of Istanbul.

\begin{tabular}{|c|c|c|c|c|c|}
\hline Family & Species, Subspecies, Varieties and Cultivars & Avcilar & Kartal & Maltepe & Sariyer \\
\hline Apocynaceae & Nerium olenader & $*$ & $*$ & & \\
\hline Arecaceae & Phoenix canariensis & & * & * & \\
\hline Asparagaceae & Agave americana 'Marginata' & * & & & \\
\hline Berberidaceae & Berberis thunbergii & $*$ & & & \\
\hline Betulaceae & $\begin{array}{l}\text { Betula pendula } \\
\text { Carpinus betulus }\end{array}$ & * & * & * & \\
\hline Caesalpiniaceae & Cercis siliquastrum & & & * & \\
\hline Celastraceae & $\begin{array}{l}\text { Euonymus japonicus } \\
\text { Euonymus japonicus 'Aureavariegata' }\end{array}$ & $\begin{array}{ll}* \\
*\end{array}$ & & & \\
\hline Cupressaceae & $\begin{array}{l}\text { Cupressus macrocarpa 'Goldcrest' } \\
\text { Cupressus sempervirens } \\
\text { Cupressus sempervirens 'Pyramidalis' } \\
\text { Juniperus horizontalis } \\
\text { Juniperus sabina } \\
\end{array}$ & $*$ & $\begin{array}{l} \\
* \\
*\end{array}$ & $*$ & \\
\hline Elaeagnaceae & Elaeagnus angustifolia & * & & & \\
\hline Ericaceae & Arbutus unedo & & & $*$ & \\
\hline Fagaceae & Quercus robur & & * & & \\
\hline Ginkgoaceae & Ginkgo biloba & & & * & \\
\hline Juglandaceae & Juglans regia & * & & & \\
\hline Magnoliaceae & $\begin{array}{l}\text { Liriodendron tulipifera } \\
\text { Magnolia grandiflora }\end{array}$ & & $*$ & * & \\
\hline Malvaceae & Tilia tomentosa & * & & & * \\
\hline Mimosaceae & Albizia julibrissin & * & * & & \\
\hline Moraceae & $\begin{array}{l}\text { Ficus carica } \\
\text { Morus nigra }\end{array}$ & $\begin{array}{l}* \\
*\end{array}$ & & & \\
\hline Oleaceae & $\begin{array}{l}\text { Fraxinus excelsior } \\
\text { Ligustrum lucidum } \\
\text { Olea europaea }\end{array}$ & & * & * & * \\
\hline Papilionaceae & Robinia pseudoacacia & * & & & * \\
\hline Pinaceae & $\begin{array}{l}\text { Cedrus atlantica 'Glauca' } \\
\text { Cedrus atlantica 'Glauca Pendula' } \\
\text { Cedrus deodora 'Aurea' } \\
\text { Cedrus libani } \\
\text { Picea pungens 'Hoopsii' } \\
\text { Pinus brutia } \\
\text { Pinus pinaster } \\
\text { Pinus pinea }\end{array}$ & * & $*$ & $\begin{array}{l}* \\
* \\
* \\
* \\
* \\
*\end{array}$ & $*$ \\
\hline Pittosporaceae & Pittosporum tobira 'Nana' & & * & & \\
\hline Platanaceae & $\begin{array}{l}\text { Platanus orientalis } \\
\text { Platanus } \mathrm{x} \text { acerifolia }\end{array}$ & $*$ & * & * & $*$ \\
\hline Rosaceae & $\begin{array}{l}\text { Cotoneaster salicifolius } \\
\text { Laurocerasus officinalis } \\
\text { Prunus cerasifera 'Pissardii Nigra' } \\
\text { Rosa } \text { sp. }\end{array}$ & $\begin{array}{l}* \\
* \\
\end{array}$ & * & & $*$ \\
\hline Salicaceae & $\begin{array}{l}\text { Salix alba } \\
\text { Salix babylonica }\end{array}$ & * & $*$ & & * \\
\hline Sapindaceae & $\begin{array}{l}\text { Acer negundo } \\
\text { Acer saccharinum }\end{array}$ & * & & * & * \\
\hline Hippocastanaceae & Aesculus hippocastanum & * & & & \\
\hline Tamaricaceae & Tamarix parviflora & * & * & & * \\
\hline
\end{tabular}

On the other hand, it was determined that the tree forms were more in the coastal areas according to the life forms of the taxa. It was found that $92.86 \%$ of the Gymnospermae taxa were trees and $7.14 \%$ were composed of shrubs. $72.97 \%$ of the Angiospermae taxa were found to be trees and $27.03 \%$ were composed of shrubs (Figure 2).

However, when the distribution of taxa according to sample areas is evaluated, it is seen that the highest rate of plants with $87.50 \%$ and seen in Avcilar region which are included in Angiospermae group (Table 2). When the distribution of taxa in coastal areas according to life forms, sub-groups were evaluated within themselves and the highest rate of taxa in tree form was found to be $100 \%$ in Maltepe, Sariyer and Kartal regions in Gymnospermae group. It was found that the highest rate of shrub form was in the group of Angiospermae in Avcrlar region with $38.10 \%$ (Table 3).

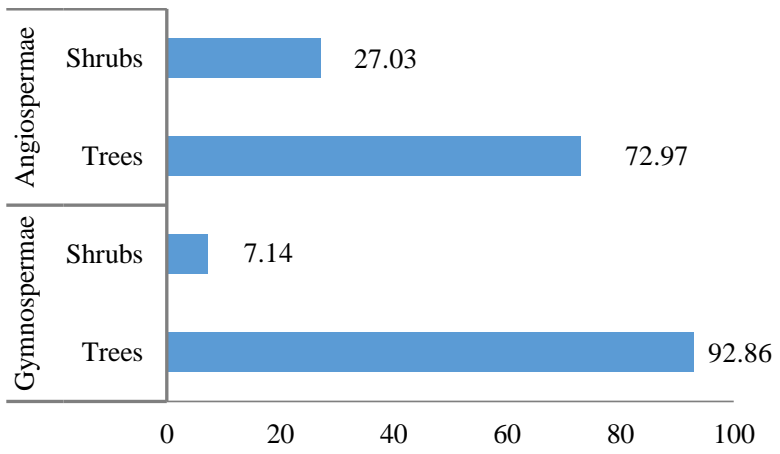

Figure 2. Life forms of plant taxa in coastal areas 
3.2. Ecological tolerances of woody plants in coastal areas of Istanbul

\subsubsection{Light tolerance}

In the evaluation of light tolerances of woody plants in the coastal areas, the highest percentage of the plants in Maltepe region with $63.16 \%$ were found to be good at the sun / partial shade environments, while the taxa in the Sariyer region were determined to have a sun and sun partial shade environment with 50\% (Figure 3). The classification of taxa according to light demands is given on Table 4 .

\subsubsection{Frost, drought, salinity and air pollution tolerances}

In this section the Gymnospermae and Angiospermae were evaluated on the basis of taxa. As a result of the evaluations of Gynnospermae taxa made in terms of frost, drought, salinity and air pollution tolerance, it is seen that the highest tolerance was to air pollution with the rate of $85.71 \% .78 .57 \%$ of them were tolerant to drought, $64.29 \%$ of them were tolerant to frost and at last $28.57 \%$ of them were found to be tolerant to the salinity (Figure 4). The classification of Gymnospermae taxa according to ecological tolerances is given on Table 5 .

Table 2. Distribution of woody plants in terms of sample areas

\begin{tabular}{lcccc}
\hline \multirow{2}{*}{ Taxa } & \multicolumn{4}{c}{ Regions } \\
\cline { 2 - 5 } & $\begin{array}{c}\text { Avc1lar } \\
(\%)\end{array}$ & $\begin{array}{c}\text { Kartal } \\
(\%)\end{array}$ & $\begin{array}{c}\text { Maltepe } \\
(\%)\end{array}$ & $\begin{array}{c}\text { Sarıer } \\
(\%)\end{array}$ \\
\hline Gymnospermae & 12.50 & 25.00 & 36.84 & 20.00 \\
Angiospermae & 87.50 & 75.00 & 63.16 & 80.00 \\
\hline
\end{tabular}

Table 3. Distribution of woody plants in terms of life forms

\begin{tabular}{lcrrrr}
\hline \multirow{2}{*}{ Taxa } & & \multicolumn{4}{c}{ Regions } \\
\cline { 3 - 6 } & & $\begin{array}{c}\text { Avclar } \\
(\%)\end{array}$ & \multicolumn{1}{c}{$\begin{array}{c}\text { Kartal } \\
(\%)\end{array}$} & $\begin{array}{c}\text { Maltepe } \\
(\%)\end{array}$ & \multicolumn{1}{c}{$\begin{array}{c}\text { Sarıyer } \\
(\%)\end{array}$} \\
\hline \multirow{2}{*}{ Gymnospermae } & Tree & 66.67 & 100.00 & 100.00 & 100.00 \\
& Shrub & 33.33 & 0.00 & 0.00 & 0.00 \\
\hline \multirow{2}{*}{ Angiospermae } & Tree & 61.90 & 66.67 & 91.67 & 87.50 \\
& Shrub & 38.10 & 33.33 & 8.33 & 12.50 \\
\hline
\end{tabular}

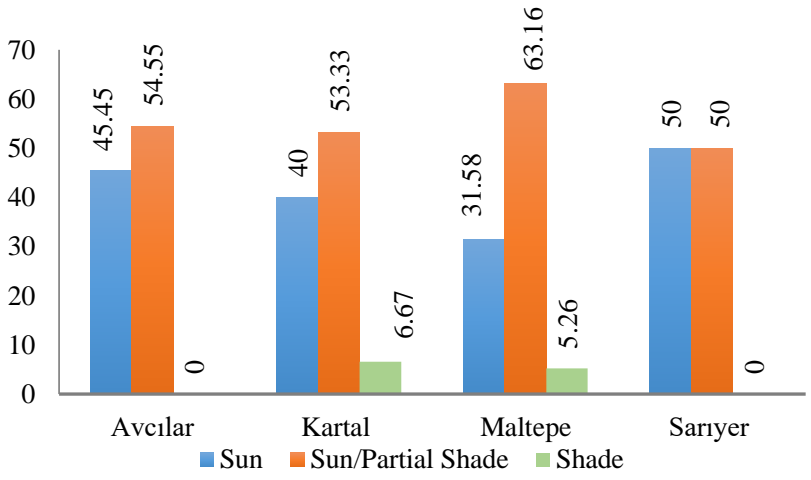

Figure 3. Light tolerance of woody plants according to sample areas

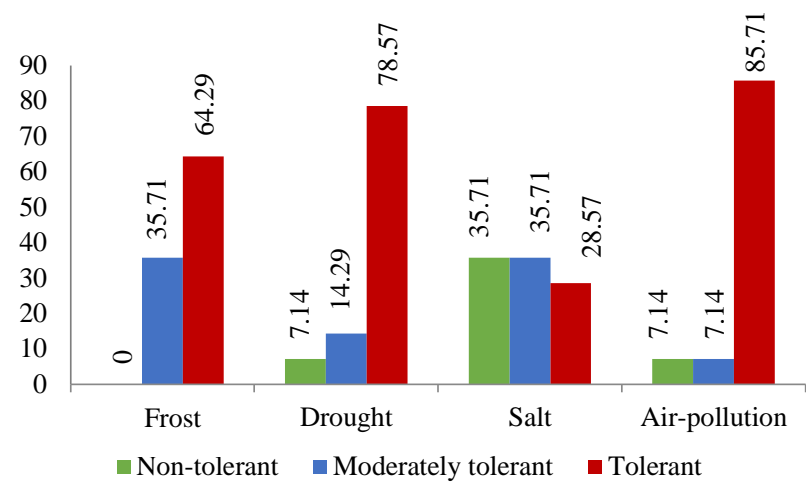

Figure 4. Tolerance distributions of Gymospermae taxa

Table 4. Classification of taxa according to light requirements

\begin{tabular}{|c|c|c|}
\hline Regions & Light tolerance & Taxa \\
\hline \multirow{4}{*}{ Avcilar } & Sun & $\begin{array}{l}\text { Agave americana 'Marginata', Albizia julibrissin, Cupressus sempervirens, Eleagnus angustifolia, Ficus carica, } \\
\text { Nerium oleander, Platanus x acerifolia, Rosa sp, Salix alba, Tamarix parviflora }\end{array}$ \\
\hline & & Acer negundo, Aesculus hippocastanum, Berberis thunbergii, Betula pendula, Cotoneaster salicifolius, \\
\hline & Sun/Partial Shade & $\begin{array}{l}\text { Euonymus japonicus, Euonymus japonicus 'Aureovariegata', Juglans regia, Juniperus sabina, Morus nigra, } \\
\text { Prunus cerasifera 'Pisardii Nigra', Robinia pseudoacacia, Tilia tomentosa }\end{array}$ \\
\hline & Shade & - \\
\hline \multirow{3}{*}{ Kartal } & Sun & $\begin{array}{l}\text { Cupressus macrocarpa 'Goldcrest', Cupressus sempervirens, Nerium oleander, Pinus pinaster, Rosa sp, Tamarix } \\
\text { parviflora }\end{array}$ \\
\hline & Sun/Partial Shade & $\begin{array}{l}\text { Betula pendula, Juniperus horizontalis, Magnolia grandiflora, Pittosporum tobira 'Nana', Platanus orientalis, } \\
\text { Lurocerasus officinalis, Quercus robur, Salix babylonica }\end{array}$ \\
\hline & Shade & Phoenix canariensis \\
\hline \multirow{3}{*}{ Maltepe } & Sun & $\begin{array}{l}\text { Arbutus unedo, Cedrus deodora 'Aurea', Cupressus sempervirens 'Pyramidalis', Fraxinus excelsior, Olea } \\
\text { europaea, Pinus pinea }\end{array}$ \\
\hline & Sun/Partial Shade & $\begin{array}{l}\text { Acer saccharinum, Betula pendula, Carpinus betulus, Cedrus atlantica 'Glauca', Cedrus atlantica 'Glauca } \\
\text { Pendula', Cercis siliquastrum, Ginkgo biloba, Ligustrum lucidum, Liriodendron tulipifera, Magnolia grandiflora, } \\
\text { Picea pungens 'Hoopsii', Platanus orientalis }\end{array}$ \\
\hline & Shade & Phoenix canariensis \\
\hline \multirow[b]{2}{*}{ Sarıer } & Sun & Cedrus libani, Fraxinus excelsior, Pinus pinea, Platanus x acerifolia, Tamarix parviflora \\
\hline & $\begin{array}{l}\text { Sun/Partial Shade } \\
\text { Shade }\end{array}$ & $\begin{array}{l}\text { Acer saccharinum, Laurocerasus officinalis, Robinia pseudoacacia, Salix babylonica, Tilia tomentosa } \\
\text { - }\end{array}$ \\
\hline
\end{tabular}


According to the one-way variance analysis conducted to determine the ecological tolerance of Gymnospermae taxa by regions, it was determined that the tolerance of the taxa against frost, drought, salinity and air pollution was significant at $\mathrm{p} \leq 0.05$ level. Accordingly, it was determined that the frost tolerance of the taxa was moderate and the Sariyer region ranked first with the rate of $100 \%$. It has been determined that the plant taxa in the Kartal region show full tolerant to frost $(75.00 \%)$. The plant species in Saryer and Maltepe region are full tolerant to drought $(100 \%)$. On the other hand, it was determined that the tolerance to salinity was moderate and the highest rate was $66.67 \%$ in Avcilar region. It was determined that the taxa in Maltepe region with $57.15 \%$ were not tolerant to salinity. It was found that plant taxa in Maltepe and Kartal region were fully tolerant $(100 \%)$ in terms of air pollution (Table 6).

When the ecological tolerances of Angiospermae taxa was evaluated, it was determined that the highest rate of tolerance was to air pollution with $64.86 \%, 56.76 \%$ of them was tolerant to frost and drought and moderate tolerant to salinity with $43.24 \%$ (Figure 5). The classification of Angiospermae taxa according to ecological tolerances is given in Table 7.
According to the results of the one-way analysis of variance made to determine the ecological tolerances of Angiospermae taxa by regions, it was determined that the resistance to frost, drought, salinity and air pollution was significant at $\mathrm{p} \leq 0.05$ level. In general, the taxa found to be tolerant to frost. The highest rate to frost tolerance was seen in Sariyer region with the rate of $87.50 \%$. In terms of tolerance to drought and air pollution, $75 \%$ and $100 \%$ of the taxa in Sariyer region were found to be fully tolerant. In salinity tolerance, the taxa were found to be moderately salt tolerant and Kartal and Maltepe regions ranked first with $41.67 \%$ (Table 8).

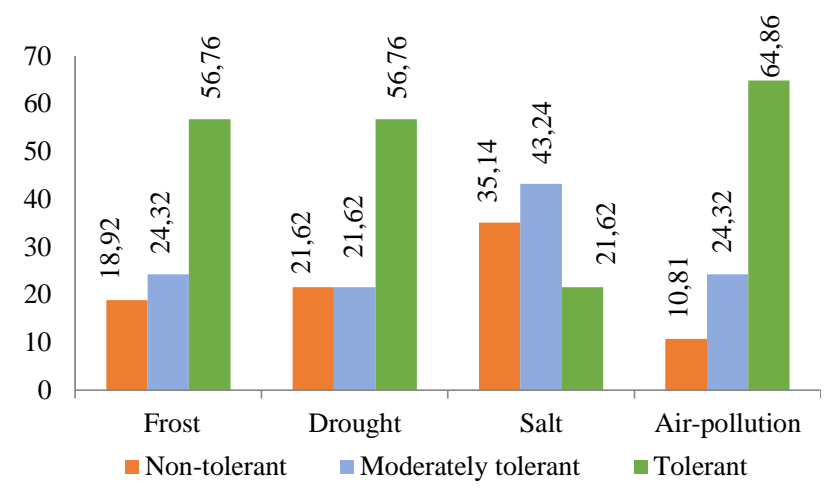

Figure 5. Tolerance distributions of angiospermae taxa

Table 5. Classification of gymnospermae taxa according to ecological tolerances

\begin{tabular}{|c|c|c|c|c|c|c|c|c|c|c|c|c|}
\hline \multirow{3}{*}{ Gymnospermaea Taxa } & \multicolumn{12}{|c|}{ Ecological tolerance } \\
\hline & \multicolumn{3}{|c|}{ Frost } & \multicolumn{3}{|c|}{ Drought } & \multicolumn{3}{|c|}{ Salinity } & \multicolumn{3}{|c|}{ Air Pollution } \\
\hline & $\mathrm{H}$ & M & $\mathrm{L}$ & $\mathrm{H}$ & $\mathrm{M}$ & $\mathrm{L}$ & $\mathrm{H}$ & $\mathrm{M}$ & $\mathrm{L}$ & $\mathrm{H}$ & M & $\mathrm{L}$ \\
\hline Cedrus atlantica 'Glauca' & $*$ & & & $*$ & & & & & $*$ & $*$ & & \\
\hline Cedrus atlantica 'Glauca Pendula' & $*$ & & & $*$ & & & & & $*$ & $*$ & & \\
\hline Cedrus deodora 'Aurea' & & $*$ & & $*$ & & & & $*$ & & & & $*$ \\
\hline Cedrus libani & & $*$ & & $*$ & & & & & $*$ & $*$ & & \\
\hline Cupressus macrocarpa 'Goldcrest' & $*$ & & & $*$ & & & & $*$ & & $*$ & & \\
\hline Cupressus sempervirens & $*$ & & & $*$ & & & & $*$ & & $*$ & & \\
\hline Cupressus sempervirens 'Pyramidalis' & $*$ & & & $*$ & & & & $*$ & & $*$ & & \\
\hline Ginkgo biloba & $*$ & & & & & $*$ & & & $*$ & $*$ & & \\
\hline Juniperus horizontalis & $*$ & & & $*$ & & & & & & $*$ & & \\
\hline Juniperus sabina & $*$ & & & $*$ & & & & & & $*$ & & \\
\hline Picea pungens 'Hoopsii' & $*$ & & & & $*$ & & & & $*$ & $*$ & & \\
\hline Pinus brutia & & $*$ & & & $*$ & & & $*$ & & & $*$ & \\
\hline Pinus pinaster & & $*$ & & $*$ & & & $*$ & & & $*$ & & \\
\hline Pinus pinea & & $*$ & & $*$ & & & $*$ & & & $*$ & & \\
\hline
\end{tabular}

(H: High tolerance - M: Modarately tolerance - L: Low tolerance)

Table 6. Ecological tolerances of gymnospermae taxa according to sample areas

\begin{tabular}{|c|c|c|c|c|c|}
\hline Tolerance factors & Tolerance rate $(\%)$ & Avcrlar & Kartal & Maltepe & Sarıyer \\
\hline \multirow{3}{*}{ Frost tolerance } & 1 (Low tolerance) & & 0.00 & 0.00 & 0.00 \\
\hline & 2 (Medium tolerance) & $33.33 \mathrm{~b}$ & $25.00 \mathrm{~d}$ & $28.57 \mathrm{c}$ & $100.00 \mathrm{a}$ \\
\hline & 3 (High tolerance) & $66.67 \mathrm{c}$ & $75.00 \mathrm{a}$ & $71.43 \mathrm{~b}$ & $0.00 \mathrm{~d}$ \\
\hline \multirow{3}{*}{ Drought tolerance } & 1 (Low tolerance) & $0.00 \mathrm{~b}$ & $0.00 \mathrm{~b}$ & $14.29 \mathrm{a}$ & $0.00 \mathrm{~b}$ \\
\hline & 2 (Medium tolerance) & $33.33 \mathrm{a}$ & $0.00 \mathrm{c}$ & $14.29 \mathrm{~b}$ & $0.00 \mathrm{c}$ \\
\hline & 3 (High tolerance) & $66.67 \mathrm{c}$ & $100.00 \mathrm{a}$ & $71.42 \mathrm{~b}$ & $100.00 \mathrm{a}$ \\
\hline \multirow{3}{*}{ Salinity tolerance } & 1 (Low tolerance) & $0.00 \mathrm{c}$ & $0.00 \mathrm{c}$ & $57.15 \mathrm{a}$ & $50.00 \mathrm{~b}$ \\
\hline & 2 (Medium tolerance) & $66.67 \mathrm{a}$ & $50.00 \mathrm{~b}$ & $28.57 \mathrm{c}$ & $0.00 \mathrm{~d}$ \\
\hline & 3 (High tolerance) & $33.33 \mathrm{~b}$ & $50.00 \mathrm{a}$ & $14.28 \mathrm{c}$ & $50.00 \mathrm{a}$ \\
\hline \multirow{3}{*}{$\begin{array}{l}\text { Air pollution } \\
\text { tolerance }\end{array}$} & 1 (Low tolerance) & $0.00 \mathrm{~b}$ & $0.00 \mathrm{~b}$ & $14.28 \mathrm{a}$ & $0.00 \mathrm{~b}$ \\
\hline & 2 (Medium tolerance) & $33.33 \mathrm{a}$ & $0.00 \mathrm{~b}$ & $0.00 \mathrm{~b}$ & $0.00 \mathrm{~b}$ \\
\hline & 3 (High tolerance) & $66.67 \mathrm{c}$ & $100.00 \mathrm{a}$ & $85.72 \mathrm{~b}$ & $100.00 \mathrm{a}$ \\
\hline
\end{tabular}

The letters show different groups at $\mathrm{p} \leq 0.05$ level 
Table 7. Classification of angiospermae taxa according to ecological tolerances

\begin{tabular}{|c|c|c|c|c|c|c|c|c|c|c|c|c|}
\hline \multirow{3}{*}{ Angiosperme Taxa } & \multicolumn{12}{|c|}{ Ecological tolerance } \\
\hline & \multicolumn{3}{|c|}{ Frost } & \multicolumn{3}{|c|}{ Drought } & \multicolumn{3}{|c|}{ Salt } & \multicolumn{3}{|c|}{ Air Pollution } \\
\hline & $\mathrm{H}$ & $\mathrm{M}$ & $\mathrm{L}$ & $\mathrm{H}$ & $\mathrm{M}$ & $\mathrm{L}$ & $\mathrm{H}$ & $\mathrm{M}$ & $\mathrm{L}$ & $\mathrm{H}$ & $\mathrm{M}$ & $\mathrm{L}$ \\
\hline Acer negundo & $*$ & & & $*$ & & & & $*$ & & & $*$ & \\
\hline Acer saccharinum & $*$ & & & & & $*$ & & & $*$ & $*$ & & \\
\hline Aesculus hippocastanum & $*$ & & & $*$ & & & & $*$ & & $*$ & & \\
\hline Agave americana 'Marginata' & & & $*$ & $*$ & & & & & $*$ & & $*$ & \\
\hline Albizia julibrissin & & & $*$ & & $*$ & & & & $*$ & & & * \\
\hline Arbutus unedo & & & $*$ & $*$ & & & & $*$ & & $*$ & & \\
\hline Berberis thunbergii & $*$ & & & & & $*$ & & & $*$ & $*$ & & \\
\hline Betula pendula & $*$ & & & & & $*$ & & & $*$ & $*$ & & \\
\hline Carpinus betulus & $*$ & & & $*$ & & & & & $*$ & $*$ & & \\
\hline Cercis siliquastrum & $*$ & & & $*$ & & & & & $*$ & & & * \\
\hline Cotoneaster salicifolius & & $*$ & & & & $*$ & & & $*$ & & $*$ & \\
\hline Elaeagnus angustifolia & $*$ & & & $*$ & & & $*$ & & & & & $*$ \\
\hline Euonymus japonicus & & $*$ & & & $*$ & & & $*$ & & & $*$ & \\
\hline Euonymus japonicus 'Aureavariegata' & & $*$ & & & $*$ & & & * & & & $*$ & \\
\hline Ficus carica & & & $*$ & $*$ & & & $*$ & & & $*$ & & \\
\hline Fraxinus excelsior & $*$ & & & $*$ & & & & $*$ & & $*$ & & \\
\hline Juglans regia & $*$ & & & & $*$ & & & & $*$ & $*$ & & \\
\hline Laurocerasus officinalis & $*$ & & & $*$ & & & * & & & $*$ & & \\
\hline Ligustrum lucidum & & $*$ & & & $*$ & & & $*$ & & $*$ & & \\
\hline Liriodendron tulipifera & $*$ & & & & & $*$ & & & $*$ & $*$ & & \\
\hline Magnolia grandiflora & & $*$ & & & & $*$ & & $*$ & & $*$ & & \\
\hline Morus nigra & $*$ & & & $*$ & & & $*$ & & & $*$ & & \\
\hline Nerium olenader & $*$ & & & $*$ & & & $*$ & & & $*$ & & \\
\hline Olea europaea & $*$ & & & $*$ & & & & $*$ & & $*$ & & \\
\hline Phoenix canariensis & & & $*$ & $*$ & & & & $*$ & & & $*$ & \\
\hline Pitosporum tobira 'Nana' & & $*$ & & & $*$ & & & $*$ & & & $*$ & \\
\hline Platanus orientalis & $*$ & & & $*$ & & & $*$ & & & $*$ & & \\
\hline Platanus $\mathrm{x}$ acerifolia & $*$ & & & $*$ & & & $*$ & & & $*$ & & \\
\hline Prunus cerasifera 'Pissardii Nigra' & & $*$ & & & $*$ & & & $*$ & & & & * \\
\hline Quercus robur & & $*$ & & & $*$ & & & $*$ & & & $*$ & \\
\hline Quercus suber & & & $*$ & $*$ & & & & & $*$ & & $*$ & \\
\hline Robinia pseudoacacia & & & $*$ & $*$ & & & & $*$ & & $*$ & & \\
\hline Rosa sp. & $*$ & & & $*$ & & & & & $*$ & $*$ & & \\
\hline Salix alba & & $*$ & & & & $*$ & & $*$ & & $*$ & & \\
\hline Salix babylonica & $*$ & & & & & $*$ & & $*$ & & $*$ & & \\
\hline Tamarix parviflora & $*$ & & & $*$ & & & $*$ & & & $*$ & & \\
\hline Tilia tomentosa & $*$ & & & $*$ & & & & & $*$ & $*$ & & \\
\hline
\end{tabular}

H: High tolerance - M: Moderately tolerance - L: Low tolerance

Table 8. Ecological tolerances of angiospermae taxa according to sample areas

\begin{tabular}{|c|c|c|c|c|c|}
\hline Tolerance factors & Tolerance rates $(\%)$ & Avcilar & Kartal & Maltepe & Sariyer \\
\hline \multirow{3}{*}{ Frost tolerance } & 1 (Low tolerance) & $19.05 \mathrm{~b}$ & $16.67 \mathrm{c}$ & $25.00 \mathrm{a}$ & $12.50 \mathrm{~d}$ \\
\hline & 2 (Medium tolerance) & $23.80 \mathrm{~b}$ & $25.00 \mathrm{a}$ & $8.33 \mathrm{c}$ & $0.00 \mathrm{~d}$ \\
\hline & 3 (High tolerance) & $57.15 \mathrm{~d}$ & $58.33 \mathrm{c}$ & $66.67 \mathrm{~b}$ & $87.50 \mathrm{a}$ \\
\hline \multirow{3}{*}{ Drought tolerance } & 1 (Low tolerance) & $19.05 \mathrm{c}$ & $25.00 \mathrm{~b}$ & $33.33 \mathrm{a}$ & $25.00 \mathrm{~b}$ \\
\hline & 2 (Medium tolerance) & $23.80 \mathrm{~b}$ & $25.00 \mathrm{a}$ & $0.00 \mathrm{c}$ & $0.00 \mathrm{c}$ \\
\hline & 3 (High tolerance) & $57.15 \mathrm{c}$ & $50.00 \mathrm{~d}$ & $66.67 \mathrm{~b}$ & $75.00 \mathrm{a}$ \\
\hline \multirow{3}{*}{ Salinity tolerance } & 1 (Low tolerance) & $38.09 \mathrm{~b}$ & $25.00 \mathrm{c}$ & $50.00 \mathrm{a}$ & $25.00 \mathrm{c}$ \\
\hline & 2 (Medium tolerance) & $33.33 \mathrm{c}$ & $41.67 \mathrm{a}$ & $41.67 \mathrm{a}$ & $37.50 \mathrm{~b}$ \\
\hline & 3 (High tolerance) & $28.58 \mathrm{c}$ & $33.33 \mathrm{~b}$ & $8.33 \mathrm{~d}$ & $37.50 \mathrm{a}$ \\
\hline \multirow{3}{*}{ Air pollution tolerance } & 1 (Low tolerance) & $14.29 \mathrm{a}$ & $8.33 \mathrm{c}$ & $8.33 \mathrm{c}$ & $0.00 \mathrm{c}$ \\
\hline & 2 (Medium tolerance) & $23.80 \mathrm{a}$ & $25.00 \mathrm{~b}$ & $16.67 \mathrm{c}$ & $0.00 \mathrm{~d}$ \\
\hline & 3 (High tolerance) & $61.91 \mathrm{~d}$ & $66.67 \mathrm{c}$ & $75.00 \mathrm{~b}$ & $100.00 \mathrm{a}$ \\
\hline
\end{tabular}

The letters show different groups at $\mathrm{p} \leq 0.05$ level

\section{Discussions and conclusion}

In this study, woody plant taxa used in some coastal landscape areas of Istanbul were evaluated in the context of ecological tolerance criteria. Accordingly, a total of 51 plant taxa were determined in the study in Avcilar, Maltepe, Kartal and Sariyer sample areas, 37 of which were angiosperm and 14 of them were gymnosperm taxa. 40 of the identified taxa were found to be tree and 11 were in shrub form.

When the light tolerances of the plants are evaluated which is one of the ecological tolerance values; generally the plants found in sample areas were good at light. 29 of them are plants that can grow in shadow areas. When we evaluate the plants in coastal areas according to regions; the highest percentage of the plants in Maltepe region with $63.16 \%$ were found to be good at sun/semi-shade environments, while the taxa in the Sarıer region with 50\% were determined to be good at sun and sun/half shadow environment.

When the gymnosperm taxa in the sample areas are evaluated in terms of frost, drought, salinity and air pollution tolerance, it is seen that the highest tolerance was to air pollution with the rate of $85.71 \%$. $78.57 \%$ of them 
were tolerant to drought, $64.29 \%$ of them were tolerant to frost. Accordingly, it was determined that the frost tolerance of the taxa was moderate and the Sarıyer region ranked first with the rate of $100 \%$. It has been determined that the plant taxa in the Kartal region show full tolerant to frost with $75.00 \%$. The plant species in Sarıyer and Maltepe region are full tolerant to drought $(100 \%)$. Indeed, in the study of Seyidoğlu Akdeniz et al. (2017) which evaluated the ecological tolerances of gymnosperm taxa of Bursa city; it has been determined that most of those species have a good performance standing on frost, drought and air pollution. It was found that the gymnospermae taxa in Bursa city were $81.4 \%$ tolerant to frost, $67.44 \%$ tolerant to drought and $86.05 \%$ tolerant to air pollution.

When the ecological tolerances of Angiospermae taxa was evaluated, it was determined that the highest rate of tolerance was to air pollution with $64.86 \%$. In general, the taxa found to be tolerant to frost. The highest rate to frost tolerance was seen in Saryyer region with the rate of $87.50 \%$. Also it is seen that plant taxa in Sariyer region show $75 \%$ tolerant to drought and show full tolerance to air pollution. In the study of Zencirkıran and Seyidoğlu Akdeniz (2017) which is the determination of woody plants of Bursa city parks in terms of ecological tolerance criteria; the taxa were found to be 80-90 tolerant to frost and air pollution. In the study of Bayramoğlu (2016) which was took place at KTU Kanuni campus, it was found that the plant species on campus are partially in line with the approach to the arid landscaping. But also it was determined that the natural species of the region have been found to be used very little in the campus area. In the study of Yazic1 et al. (2014), which was stated in landscape designs of Isparta; although 22 of 57 plant species used were not natural species, it was concluded that the water demand was moderate/less, and only 8 species had a high water demand.

Salinity is one of the most important criteria to be considered in coastal areas. Because the coastal areas are one of the most difficult landscaping areas with salty water effects coming from the sea and soil, strong winds and moisture, as well as a limited development environment due to the degrade soil (Korkut, 1992). Due to the results of this study which took place on the coastal landscape areas of Istanbul, $28.57 \%$ of the gymnosperm taxa were found to be salinity tolerant. Plant taxa in Avcılar landscape areas were determined to be $66.67 \%$ tolerant to salinity; Maltepe was found to be the least salinity tolerant sample area in the scope of gymnosperm taxa, with the rate of $57.15 \%$. Seyidoğlu Akdeniz et al. (2017) found out that the gymnosperm taxa of Bursa city was $34.56 \%$ tolerant to salinity.

Angiosperm taxa was found to be moderately tolerant to salinity with a ratio of $43.24 \%$. Kartal and Maltepe have a moderate tolerance to salinity with a rate of $41.67 \%$. In the study of Zencirkıran and Seyidoğlu Akdeniz (2017) it was determined that the woody plants of Bursa city parks were tolerant to salinity at $60-65 \%$ ratio.

As a result, in this study, it was determined that some plant taxa which are tolerant to ecological factors such as frost, drought and air pollution were used in the coastal areas in Istanbul, whereas salt tolerance was found to be neglected. The ecological approach in plant taxa used in coastal areas has been taken into consideration. However, the same for salinity tolerance can not be said. Due to the low and moderate tolerance of salinity in coastal areas, it is inevitable that various developmental disorders will be seen on plants in time. In order to create sustainable landscape designs, plants with high salinity tolerance should be preferred especially in coastal areas where high salinity effects are seen. In this context, in coastal landscape areas using salinity tolerant tree species like; Ailanthus altissima, Elaeagnus angustifolia, Fraxinus excelsior, Gleditsia triacanthos, Platanus orientalis, Populus alba, Robinia pseudoacacia 'Umbraculifera', Salix alba, Salix babylonica, and shrub species like Atriplex halimus, Baccharis halimifolia, Cotoneaster franchettii, Pittosporum tobira, Pyracantha coccinea, Tamarix pentandra; is very important for creating sustainable coastal landscapes.

\section{References}

Barış, M.E., 2014. Kurakçıl Peyzaj "Xeriscape”. İklim Değişikliğine Yerel Çözümler: Doğal Bitki Örtüsüyle Sürdürülebilir Uygulamalar Eğitim Kitapçı̆̆ı, Peyzaj Araştırmaları Derneği Yayınları, Ankara. pp: 55-90.

Bayramoğlu, E., 2016. Sürdürülebilir peyzaj düzenleme yaklaşımı: Karadeniz Teknij Üniversitesi Kanuni Kampüsü'nün xeriscape açısından değerlendirilmesi. Artvin Coruh University Journal of Forestry Faculty, 17(2): 119-127, ISSN:2146-1880, e-ISSN: 2146-698X

Bhardwaj, B.M., Singh, S., 2015. Air pollution tolerance of ornamental trees in industrial city. Hortflora Research Spectrum, 4(3): 185.

Brickell, C., 1994. The Royal Horticultural Society Gardeners' Encyclopedia of Plants and Flowers. New Edition. Dorling Kindersley, London.

Davis, P.H., 1965-1988. Flora of Turkey and the East Aegean Islands. Edinburgh University Press. Vols 1-10, Edinburgh.

Dirr, M.A., 1992. Manual of Woody Landscape Plants: Their Identification, Ornamental Characteristics, Culture, Propagation and Uses. Varsity Press, IL, USA.

Ebben Nursery, 2017b. https://www.ebben.nl/en/treeebb. Accessed: 10.08.2018.

Escobedo, F., Chacalo, A., 2008. Reduction in atmosphere pollution due to the urban trees in Mexico city (Descontaminación Atmosférica Por El Arbolado Urbano De La Ciudad De México). Interciencia, 33: 29.

Gilman, E.F., Watson, D.G., 1993. Environmental Horticulture University of Florida. Institute of Food Fact Sheet ST-107. http://hort.ufl.edu/database/trees/trees_scientific.shtml, Accessed: 22.12.2018.

Gönensin, S., 2002. İstanbul'un avrupa yakasının peyzaj ekolojisi açısından incelenmesi. Doktora Tezi, İstanbul Üniversitesi Fen Bilimleri Enstitüsü, İstanbul, Turkey.

Grahn, P., Stigsdotter, U.A., 2003. Landscape planning and stress. Urban Forestry \& Urban Greening, 2(1): 1-18.

Güvenç, İ., Demiroğlu, D., 2016. Kilis 7 Aralık Üniversitesi merkez yerleşkesi yeşil alanlarının "xeriscape" (kurakçıl peyzaj düzenlemesi) açısından değerlendirilmesi. ISEM2016, 3rd International Symposium on Environment and Morality. 04-06 November, Alanya-Turkey, pp: 389-400.

Hillier, J., 2001. The Hillier Manual of Trees And Shrubs. Royal Horticultural Society; 8th Revised edition edition. ISBN13: $978-1907057472$

Hopkins, E., Al-Yahyai, R., 2015. Landscaping with native plants in Oman. VIII International Symposium on New Ornamental Crops and XII International Protea Research Symposium 1097. August 2015, pp. 181-192.

İBB, 2006. İstanbul Büyükșehir Belediyesi İmar ve Sehircilik Daire Başkanlı̆̆ı, Şehir Planlama Müdürlüğü, 1/100000 Ölçekli İstanbul çevre düzeni planı raporu, 3. Bölüm-İstanbul il bütünü araştırma bulguları, Accessed: 15.11.2007. 
Korkut, A.B., 1992. Peyzaj Mimarlı̆̆ı. ISBN: 975-8377-15-9. Hasad Yayıncılık Ltd.Şti., İstanbul.

Korkut, A., Kiper, T., Üstün, T., 2017. Kentsel peyzaj tasarımda ekolojik yaklaşımlar. Artium, 5(1): 14-26.

Krussmann, G., 1985. Manual of Cultivated Conifers, Timber Press, Oregon, ISBN: 0-88192-007-X.

Krussmann, G., 1986. Manual of Cultivated Broad-Leaved Trees \& Shrubs, Volume III, PRU- Z, Timber Press, Oregon, ISBN: 088192-006-1.

Orçun, E., 1972. Dendrology. Vol. I. Coniferous Trees and Shrubs, Ege Univ Faculty of Agriculture, Publication No: 196, Izmir.

Özyuvac1, N., 1999. Meteoroloji ve Klimatoloji, İstanbul Üniversitesi Orman Fakültesi Yayınları, Rektörlük No. 4196, Fakülte No. 460, ISBN: 975-404-544-5, İstanbul.

Pamay, B., 1992. Bitki Materyali I: Ağaçlar ve Ağaçcıklar. Uycan Matbaası, İstanbul.

Pamay, B., 1993. Bitki Materyali II: Odunsu Kökenler-Çiçekli Çalılar, Sarmaşıklar, Kaktüsler ve Sukkulent Bitkiler, Saz ve Kamışlar. Orhan Ofset, İstanbul.

PFAF., 2009. Plant Database Search Page, Plants for a future edible, medicinal and useful plants for a healthier world, http://www.pfaf.org/database/index.php,

Accessed: 22.10.2017.

Plants., 2017. NC State University Extension. https://plants.ces.ncsu.edu., Accessed: 15.10.2018.

Plants Database, 2018. http://plants.usda.gov/, Accessed: 20.07.2018.

Polunin, O., 1969. Flowers of Europe. Oxford University Press, London.

Rayno, V., 2014. The Water Efficient Landscape. Swedish University of Agricultural Sciences. $56 \mathrm{p}$.

Seyidoğlu Akdeniz, N., Ender, E., Zencirkıran, M., 2017. Evaluation of ecological tolerance and requirements of exotic conifers in the urban landscape of Bursa. Fresenius Environmental Bulletin, 26(10): 6064-6070.
Türer, F.A., 1999. İstanbul kenti sahil dolgu alanlarının peyzaj planlaması açısından değerlendirilmesi. Yüksek Lisans tezi, İstanbul Teknik Üniversitesi Fen Bilimleri Enstitüsü, İstanbul.

The Gymnospermae Database, 2019. http://www.conifers.org/, Accessed: 10.04.2018.

Ürgenç, S., 1998. Ağaçlandırma Tekniği. İstanbul Üniversitesi Orman Fakültesi Yayın No: 441/3994. İstanbul.

Wade, L.G., Midcap, T.J., 2007. Xeriscape a Guide to Developing a Water-Wise Landscape. University of Georgia Environmental Landscape Department, $40 \mathrm{p}$.

Yaltırık, F., 1988. Dendroloji Ders Kitabı II, Angiospermae (Kapalı Tohumlular), İstanbul Üniversitesi Orman Fakültesi Yayınları, İstanbul Üniversitesi Yayın No: 3509, Orman Fakültesi Yayın No: 390, İstanbul.

Yaltırık, F., 1993. Dendroloji Ders Kitabı, Gymnospermae (Açık Tohumlular), İstanbul Üniversitesi Orman Fakültesi Yayınları, İstanbul Üniversitesi Yayın No: 3443, Orman Fakültesi Yayın No:386, İstanbul.

Yaltırık, F., Efe, A., 2000. Dendroloji Ders Kitabı, GymnospermaeAngiospermae. İstanbul Üniversitesi Orman Fakültesi Yayınları, İstanbul Üniversitesi Yayın No:4265, Orman Fakültesi Yayın No:465, İstanbul.

Yazıcı, N., Dönmez, Ş., Kuş Şahin, C., 2014. Isparta kenti peyzaj düzenlemelerinde kullanılan bazı bitkilerin kurakçıl peyzaj tasarımı açısından değerlendirilmesi. Kastamonu Üniversitesi, Orman Fakültesi Dergisi, 14(2): 199-208.

Yener, D., 2012. İstanbul'da peyzaj düzenlemelerinde kullanılan odunsu bitkiler üzerine araştırmalar. Doktora tezi, İstanbul Üniversitesi Fen Bilimleri Enstitüsü, İstanbul.

Zencirkıran, M., Seyidoğlu Akdeniz, N., 2017. Bursa kent parkları odunsu bitki taksonlarının ekolojik tolerans kriterleri açısından değerlendirilmesi. Journal of Bartin Faculty of Forestry, 19(2): 11-19. 